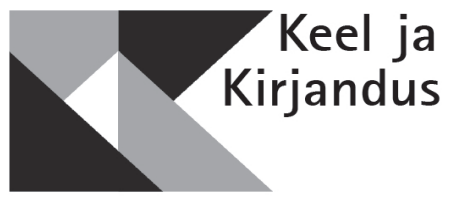

\title{
RAAMATUTEST JA LUGEMISEST BALTISAKSA MEMUARISTIKA VALGUSES
}

\author{
REET BENDER
}

Ja ise lugedes õppisin ma rohkem

kui ülikoolis loengutel käies

(O. Hartge)

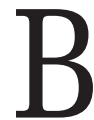

altisaksa memuaristika pakub mitmekesist sissevaadet Eesti kultuuriajaloo ühte osasse, olles oluline ühest küljest oma hulga, teisalt aga uudsuse võlu poolest. Eesti keelde on teadaolevalt tõlgitud sadakonna autori tekste või tekstikatkeid. Sellest hoolimata on baltisaksa memuaristikal üht-teist pakkuda just oma suhtelises tundmatuses (vrd Bender 2017), mille on tinginud üleüldine baltisaksa tekstide tundmatus, kõrvalisemate, kuid mitte vähem huvipakkuvate tekstide suur hulk ja tänasel päeval ka keeleküsimus, mis samuti seab ligipääsule oma piirangud. Memuaristika olulisust tuleb rõhutada just väärtusliku allikana balti argielu vaatlemisel.

Baltisaksa memuaristikast leiab nii mõndagi lugemise ja lugemisvara kohta - eelkõige just seetõttu, et mälestusi on valdavalt kirjutanud inimesed, kelle eluteel on raamatutel olnud teatud roll ja kes neid seetõttu ka erinevates seostes oma memuaarides mainivad. Leidub ka tekste, kus kõige muu - mälestuste autori jaoks relevantsema - kõrval mainitakse lugemist ja raamatuid vaid möödaminnes, peamiselt kooli kontekstis (nt Krusenstjern 1979; Buxhoeveden 1990; Lindenberg 1986; Baranow 1941; Schilling 1982). Memuaarid edastavad seega isikliku vaate baltisaksa lektüürile ja lugemisharrastusele. Aga lisaks 
teadmisele, mida loeti, pole vähem oluline see, kuidas, kus ja kellega loeti, kuidas lugema õpiti ja kirjavara hangiti, millised olid hoiakud lugemise suhtes.

Artiklis käsitletav ajavahemik on üpris pikk, ulatudes XVIII-XIX sajandi vahetusest kahe maailmasõja vahelise ajani. On loomulik, et igal järgnevalt esitatud näitel on oma taust ja kontekst: näiteks kooli roll hariduse omandamisel oli Teise maailmasõja eelsetel aastatel oluliselt suurem kui filosoofilise aastasaja ehk XVIII sajandi lõpul. Teisalt aga ei teinud alates XIX sajandist baltisakslaste meele- või vaimulaad läbi kuigi kardinaalseid muudatusi: Liivimaa vaikelu püsis mentaalselt ka veel ümberasumise aegu, nõnda et moodsa maailma arengutes satuti aastal 1939 äkitselt nn vaimsest biidermeierist „(maa)ilmade vahele" (vrd Boetticher 2016). Siin esitatud varasema ajajärgu näidetes võib märgata teatud ühtelangevust seniste uurimistulemustega, mille kohaselt aadlisoost baltisakslannad oma lastega ise eriti ei tegelenud (Plath 2011). Lisaks teatud üldisematele hoiakutele tulenes see ilmselt laste arvukusest ning tugivõrgustiku olemasolust. XIX sajandi teisel poolel on aga - vähemalt käesolevates näidetes - kohati näha suurt pühendumust laste harimisele. Seda toetas ühelt poolt kindlasti toonane balti naiste küllaltki hea üldhariduslik seis, võrreldes näiteks Saksamaaga (Lukas 2006: 195-197), teisalt aga ka elu üldine odavus, mis võimaldas majapidamistöödeks palgata rohkelt teenijaid ja jättis seeläbi vaba aega. XIX sajandi lõpukümnendeiks oli hariduselu jõudnud tugeva institutsionaliseerimise ajajärku, seda ennekõike saksa linnakoolide ja kõrgema astme koolide näol. Venestusajal suurenes seevastu taas koduõppe osakaal, sest muukeelne haridus oli lubatud eraõppe vormis, mida nüüd erinevate internaatide ja koduste ringidena aktiivselt organiseeriti (vrd Steinwand 1968: 34). 1905. aasta revolutsiooni järel oli saksakeelne kooliharidus taas lubatud, et Esimese maailmasõja ajal saksa keele keelustamise tõttu üldse põranda alla minna. Baltisaksa koolitegelane Marie Steinwand (neiuna Rathlef) nimetab „nähtamatuks kooliks” toonast tegevust, kui kodus tohtis õpetada lapsi ainult ükshaaval, erandiks vaid õed-vennad (Steinwand 1968: 53-58). Emakeelse hariduse saamise nimel tehtud elumuudatusi on kirjeldanud ka kaks kirjanikku, Werner Bergengruen ja Otto von Taube, kelle vanemad lahkusid venestusajal terve perekonnaga kodumaalt.

Kuna memuaare on kirjutanud eelkõige siinse saksa elanikkonna ülemad seisused, võimaldavad järgnevad näited teha mõnesuguseid järeldusi umbes viiendiku Balti provintsides elanud sakslaste lugemiskogemuste kohta: just nii suure osa moodustasid siinsest saksa elanikkonnast aadlikud, literaadid, ametnikud, suurkaupmehed, töösturid, jõukamad käsitöölised jne. Baltikumi saksa elanikkonna suurem osa olid aga nn väikesakslased, Kleindeutsche: pudupoodnikud, mitmesugused käsitöölised ja ametimehed maal ja linnas, kes memuaare pigem ei kirjutanud. ${ }^{1}$ Üht-teist siiski leidub: nii avavad Riiast pärit püttsepapere lugemisharjumusi siitkandi ainsa nobelisti Wilhelm Ostwaldi (1853-1932) mälestused. Ostwaldis äratas kultuurihuvi eelkõige ema:

Ma imestan ikka veel seda, kuidas mu ema sai vähese abiga hakkama suure majapidamise laitmatus korras hoidmisega, leides selle kõrvalt veel aega raa-

${ }^{1}$ Selliste haruldaste eestikeelsete memuaartekstide näiteks on Tartu ehitusmeistri Wilhelm Sternfeldti abikaasa mälestused (Sternfeldt 2010). 
matute ja ajakirjade lugemiseks ning suutes hoida endas alal teatud ja üldsegi mitte kitsast vaimse tegevuse ringi. [---] Meie vahel tekkis vaikne huvideseltslus, mis eraldas meid mõnevõrra teistest pereliikmetest, kelle juures sellised kalduvused nii tugevalt ei avaldunud. Kuid nagu see sellistel juhtudel ikka läheb, kasvasin ma peatselt välja sellest ringist, millega mu ema igapäevase koduse töö ja lastega kaasneva koorma all piirnema pidi, ja läksin omnivoorse lugejana oma teed, mida ema mul armastavalt, kui ka pead vangutades teha laskis. (Ostwald 1926: 13-14)

Ülemkihti kuulumine ei pruukinud samal ajal tähendada vaimuvaralembust. Iseäranis Kuramaa aadlikke ei olevat saanud süüdistada erilises tarkuse tagaajamises. Levinud anekdoodi kohaselt peeti kuramaalasi teiste baltisakslaste seas bibliofiilideks juba siis, kui neil oli kaks raamatut. Säärase „raamatukogu” koosseis varieerub jutust juttu: nimetatakse nii piiblit kui ka levinud kalendrit, aga samuti ajakirja Waidmannslust (Jahimehe Rõõm) ja Reußi printsi käsiraamatut kutsariameti finessidest (Schroeder 1943: 34); teistel andmetel oli jällegi tegu ajakirja Wild und Hund $^{3}$ (Jahiloomad ja Koerad) terve köidetud aastakäiguga, Reußi printsi sulest pärines aga hoopis teos nepijahi iseärasustest (Kraus 1941: 73). Kindlasti oli vahel tegu ka naabrite puhtakujulise kiusu ja kadedusega, nagu loos Liivimaa härrasmehest, kes ööbis ühes Kuramaa mõisas ning küsis endale õhtuks lektüüri, mispeale kohkunud majaperemees oma perekonna poole pöördus: „Meie külaline tahab lugeda, kus on lugemiseraamat?!" (Schroeder 1943: 33) Kuid vähemalt Kuramaa literaadid olid lugemishimulised, järgnev näide pärineb küll ilukirjandusest: romaanis „Kallis Renata” kirjeldatakse ilmasõja eest Kuramaalt Tartusse põgenenud baltisaksa pastoriperet, kus lisaks töökatele poegadele oli ka töökas, kuid samavõrra lugemishuviline ema, kes supikeetmise ajal luges Reclami kirjastuse ${ }^{4}$ pehmekaanelises köites „Odüsseiat”.

Et õppimine ja raamatutarkus kuulusid elus edasijõudmise või vähemalt sotsiaalse staatuse säilitamise juurde, viitab Erich Pabst, tsiteerides üht baltisaksa literaati, kes oma poja kaunis mõõdukate tulemustega koolitunnistust nähes olevat öelnud: „Poiss, sa pead õppima! Muidu saab sinust trammirööbaste rookija või pesunaise mees!” (Pabst 1998: 123)

Artikli aluseks olev lugemisteemaline tekstikorpus on tekkinud artikli teemaga haakuvalt: ulatuslikust hulgast baltisaksa tekstidest, mida autor on ajapikku lugenud, ongi tehtud käesolev näidetevalik, üritades sealjuures hõlmata erinevaid seisusi, kohti, sugusid ning ajaperioode. Võimalust mööda on kasutatud seni eesti keeles ilmumata tekste, et tutvustada uusi allikaid, mis on väärtuslikud just oma argiajaloolise andmestiku poolest (andes väikese panuse raamatu- ja lugemisloo kujutamisse Eestis just XIX ja varase XX

\footnotetext{
${ }^{2}$ Juhul kui ei ole märgitud teisiti, on tsitaadid esitatud artikli autori tõlkes. Tsitaatides esinevates teoste pealkirjades on jäetud saksakeelne pealkiri esikohale siis, kui pole leitud levinud eestikeelset tõlkevastet. K. E. von Baeri tsitaatide puhul osutus kohati asjakohasemaks lähtumine originaaltekstist (1865) ja uue, täpsustatud tõlke tegemine.

${ }^{3}$ Võimalik, et tegu on 1895. aastast Hamburgis ilmumist alustanud ajakirjaga Wild und Hund: Zeitschrift für Jäger und andere Naturfreunde.

${ }^{4}$ Kahetsusväärsel kombel on sellest eestikeelses tõlkes saanud „reklaamköide” (vrd Hueck-Dehio 2001: 175 ja Hueck-Dehio 1955: 225).
} 
sajandi vaates). Alljärgnevalt vaadeldakse baltisaksa memuaristikas leiduvaid lugemise ja raamatute kohta käivaid näiteid kahe suurema teemaploki kaupa: esiteks lugema õppimine ja (ette)lugemine, teiseks lektüüri sisu ja selle hankimine. Kummagi teema siseselt liigutakse kronoloogiliselt, alustades XVIII-XIX sajandi vahetusega ja jõudes kahe ilmasõja vahelisse perioodi, samuti vaadeldes perioodi jooksul toimunud muutusi ja arenguid.

\section{Lugema õppimine ja (ette)lugemine}

Kui aastal 1853 Riias käsitöölise perekonnas sündinud Wilhelm Ostwald õppis varaküpse lapsena lugema möödaminnes, aeglasema arenguga vanema venna kõrvalt (Ostwald 1926: 14), siis Põhja-Eestis mõisaomaniku perekonnas sündinud ja kasvanud Karl Ernst von Baer (1792-1876) õppis lugema tahtmisest ,järele jõuda vanemale vennale ja õele, kes tundusid [---] tohutult targad” (Baer 2015: 29). Baer kasvas üles onu peres, sest isa ja lastetu onu olid otsustanud lapsed vennalikult jagada (2015: 19). Onu seletas Baerile küll vabas vormis ilmaasju, kuid süstemaatilist kooliharidust ei jagatud, nõnda et kaheksandat eluaastat käiv Karl Ernst tähti veel ei tundnud. Kui majja tulid uued kasulapsed, viidi Baer vanematekoju tagasi. Baer pidas esimesi eluaastaid väga õnnestavateks: „Nüüd oli mu jõud küps, ma olin koguni hakanud veidi häbi tundma, et ma veel lugeda ei osanud; mul oli suur soov lugema õppida" (Baer 1865: 26). Sarnast maaoludes levinud laste ühist õppetööd on ligi 80 aastat hiljem kirjeldanud ka pastorisuguvõsast pärit baltisaksa koolimees Carl Hunnius (1873-1964), kes kasvas Mahu kirikumõisas, kus võeti lisaks kasvatadaõpetada ka sugulaste lapsi (Hunnius 1985: 22).

Saksakeelsetes maades ja Skandinaavias levinud nn kukeaabitsat (vrd Põldvee 2011: 69) meenutab Baer:

Mulle kingiti lihtne, eht-Tallinna moodi trüki ja väljanägemisega aabits, mille esimesel leheküljel olid suurelt trükitud üksikud tähed, millele järgnesid silbid, seejärel mõned katekismusepalad ja viimasel lehel oli kõige lihtsamas maneeris kujutatud suurt kukke ja paari väikest tibu, selle alla oli trükitud manitsus: „Kukk ergutab reipusele. Üles, koolijüts, jõua kooli õigeks ajaks!” (Baer 1865: 27)

Guvernant ütles mulle alguses tähti ette, selleks kulus paar päeva. Siis läks vanal viisil veerimiseks, sest uutest meetoditest ${ }^{5}$ ei pidanud õpetajanna lugu, kui ta neist kuulnudki oli. Mind aga võlus kõige enam kukk oma targa nõuandega. Üleüldse oli aabits minu meelest väga väärt ja tähtis raamat, see oli mu esimene raamatuvara, millest sai mu tulevase raamatukogu alus. Varem polnud minu kätte usaldatud ühtegi raamatut [---] Kuna mul oli väga hea mälu, siis jäi sisu mulle meelde ja pealkirju ning silpkirja jälgides, avastasin endalegi üllatuseks, et ma oskan lugeda, ilma et oleksin arugi saanud, kuidas see juhtus. Lugema õppimine võis võtta kaks, kõige rohkem kolm nädalat. (Baer 2015: 30-31)

${ }^{5}$ Veerimis- ja häälikumeetodi võitlusest lugema õpetamise ajaloos vt Põldvee 2011: $69-71$. 
Kukke meenutab hea sõnaga Baerist üle veerandsaja aasta noorem August Wilhelm Theodor Schwartz (1825-1904), kes sündis Kuramaal Miitavis vaeses kingsepaperes ja kellest hiljem sai Tartu Jaani koguduse õpetaja:

Kunas ma „õppima” hakkasin, ei oska ma öelda, kuid igatahes pidi see kaunis varakult olema [---] Minu ema osaks oli tutvustada mulle kõigi teadmiste algust, tähestikku; mu isal ilmselt puudus selleks tarvilik kannatlikkus. Auväärne aabits, suure punase kuke pildiga viimasel leheküljel, kui elavana seisad sa mul veel tänaselgi päeval silme ees, kuigi ma enam ühtegi sinutaolist aabitsat enam palju-palju aastaid näinud pole! (Schwartz 2007: 13)

Eesti traditsioonis ikoonilise ema voki kõrval aabitsast lugemaõppimisele sarnast olukorda on kirjeldanud Tartu ülikooli raamatukogu bibliotekaar Emil Anders (1806-1887), kellel linnalikus keskkonnas asendas vokki küll sukakudumine: „Lugema õppisime me emalt, istudes taburetil tema jalgade juures. Sukakudumiselt silmi tõstes suutis ta meile sukavarda abil leidlikult aabitsatähed selgeks õpetada, nii et me oskasime oma kuuendaks sünnipäevaks soravalt lugeda, millele meie isa rõhku pani." (Anders 2012: 9) Kasvatuseeskujusid ammutas ema Rousseau „Émile’ist”, pannes teose järgi ka pojale nime. Anderski õppis lugema teiste lastega üheskoos:

Ma kuulasin aeg-ajalt oma vanema õe õige vaevalist veerimist pealt, sest mul ei olnud muud teha, ja nii õppisin ma tahes-tahtmata koos temaga. Lugemine ei olnud minu jaoks üldse mingi nõiakunst: juba varakult ei pidanud ma end andekaks, kuid õppisin lugemise ometi nii kergesti selgeks. Hiljem õpetas mulle kogemus, et eriti elavad ja närvilise moega lapsed, kes ilmutavad hiljem erakordset andekust, saavad mehaanilise lugemise selgeks alles kahe aastaga. Minu arvates tuleks lugemisõpetusega alustada pigem alles pärast seitsmendat eluaastat. Samuti usun ma, et uut häälimismeetodit ei tuleks mitte iga lapse puhul eelistada veerimisele. (Anders 2012: 15-16)

Schwartz nimetab lugema õppimise meetodina veerimist: „Kui mu armsal emal aega oli, võttis ta mind raamatuga oma kõrvale, aeg oli aga asi, mida tal oli varuks kõige vähem. [---] On arusaadav, et ta ei saanud sellele iga päev pühenduda; et ma talle selle aga liialt raskeks oleksin teinud, ei või ma öelda, sest kui ma olin juba tähed jõudnud ära õppida, hakkasin ma vapralt veerima a b - ab jne." (Schwartz 2007: 14) Säärase omal käel veerimise peale oli ka lugemine järsku käes: „Seal juhtus midagi, millel oli mu stuudiumile pöördeline tähendus. Ühel pärastlõunal võtsin ma kätte Ewersi õpiku, ${ }^{6}$ mille järgi mind õpetati, lõin selle lahti, mu silmad jäid ühe jutukese pealkirja peale pidama - seal oli, kui ma ei eksi, juttu ausameelsest korstnapühkijapoisist - ja ennäe! Ma lugesin soravalt terve mulle tundmatu jutu suure huviga lõpuni."

\footnotetext{
${ }^{6}$ Tartu ülikooli rektori Johann Philipp Gustav Ewersi (1779-1830) 1824. aastal ilmunud saksakeelne kohalikele oludele kohandatud algkooliõpik „Erstes Schulbuch für die deutsche Jugend im Lehrbezirke der Kaiserlichen Universität Dorpat” (Esimene kooliraamat keiserliku Tartu ülikooli õpperingkonna saksa koolinoortele”), mis aasta hiljem tunnistati parimaks algkooliõpikuks Venemaal ja võeti Tartu õpperingkonna koolides laialdaselt kasutusele ning oli käibel veel 1860. aastatelgi. Vt lähemalt Leppik 2001: 172-174.
} 
(Schwartz 2007: 14) Nii sai alguse „lugemishullus”, mille ees ükski „trükitud asi ei võinud end kindlana tunda" (Schwartz 2007: 15).

Schwarzi kaasaegne Georg von Oettingen (1824-1916), hilisem Tartu ülikooli rektor ja Tartu linnapea, oli sündinud Põhja-Liivimaal mõisaomaniku perekonnas. Ta kirjeldab ealiselt varaselt ja ladusalt kulgenud lugema õppimist ühes vennaga, ${ }^{7}$ lisaks alustati varakult ka vene ja prantsuse keele õpingutega: „Peale mu neljaseks saamist hakkas ema mulle lugemist õpetama; umbes aasta hiljem hakkasime ühes vend Augustiga saama õpetust meie Gamma ${ }^{8}$ juures" (Oettingen 1926: 131). Kui vanaema käis majandamas Mõisamaa karjamõisa, võttis ta lapsed kaasa, kes siis toimetuste ajal oma ülesandeid tegid. Nii võib sedastada, et laste õpetamine ei seganud majapidamise korraldamist ei kingsepa ega mõisniku peres.

Ettelugemist - ja ka jutustamist - praktiseeriti baltisaksa memuaristika põhjal väga palju, mis justkui kinnitaks ka baltisaksa omamüüti baltisakslastest kui jutuvestjatest (vrd Boehm 1958), kellele on juttude rääkimine, anekdoodikultuur (baltisaksa Pratchen) oluliseks osaks seltskondlikkusest ja perekondlikkusest. Oma roll oli ilmselt ka valgusallikate arengul ja hinnal: rohkem näiteid ettelugemisest leidub alates XIX sajandi teisest poolest. Oettingen on näiteks meenutanud kokkuhoidlikku eluviisi mõisas veel 1830. aastatel, kui rasvaküünalde säästmiseks peeti võimalikult pikalt videvikku ja veedeti aega laulmisega (Oettingen 1926: 133). Ligikaudu samast perioodist on jutustamist kirjeldanud Schwartz, kes majanaabrist muinasjutuvestja ära kolides hakkas ise ümbruskonna lastele lugusid rääkima:

Kui mamsel Stabusch ära kolis, asusin mina tema asemele ja minust sai sama ruttu sama armastatud jutuvestja. Kust võtsin ma aga oma lood? Ma ei mõelnud neid välja, see oleks mulle tundunud kuulajate petmisena ja see poleks neid ka rahuldanud. Küll kasutasin ma jutustamiseks lugusid, mis ma olin emalt või isalt kuulnud, peamiselt aga seda, mida olin ise lugenud. [---] Tõeliseks varalaekaks oli mul üks vana paks raamat haldjamuinasjuttudega, minu toonase maitse ja arvamuse kohaselt nii suurepäraselt kirjutatud, et ma hiljem enam midagi võrreldavat pole leidnud. Aga ma oskasin ka, heale mälule tuginedes, jutustada ümber terveid romaane, mida olin lugenud; mida rohkem seiklusi ja hirmsaid lugusid seal ette tuli, seda parem, seda tänulikumate

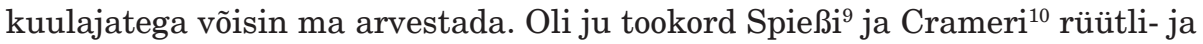
kummituslugude aeg, ja neid lugusid leidus mu isa raamatukogus kenakesel hulgal. (Schwartz 2007: 30)

Ühise juturääkimise tava oli elav ka XIX sajandi lõpul: Tartus tegutsenud preili Marie Muyscheli tütarlastekooli pansionis elas tollal tulevane kirjanik Theophile von Bodisco (1873-1944), kes õhtusöögieelsetel juturääkimistel

\footnotetext{
${ }^{7}$ August von Oettingen (1823-1908), jurist ja hilisem Riia linnapea.

${ }^{8}$ Vanaema Charlotte Ottilie, sündinud von Buxhoevden (1780-1856).

${ }^{9}$ Christian Heinrich Spieß (1755-1799), näitleja ja kirjamees, näidendite, fantaasia- ja oudusromaanide autor.

${ }^{10}$ Kirja-ja metsamees Carl Gottlob Cramer (1758-1817), hulga rüütli-ja röövliromaanide autor.
} 
tavatses pajatada oma vanaisa, Kolga mõisniku krahv Karl Magnus Stenbocki isikuga seotud üleloomulikest seikadest (Bodisco 1997: 79-80).

Põneva, tänases päevas mõneti uskumatuna tunduva näite ettelugemisest kui ühisest, koguni kergelt maanilisest ajaveetmisviisist leiab XIX sajandi algusaastate Tartust. Antud juhul sobib see, anonüümse tudengi kirjeldatuna, hästi illustreerima baltisaksa Schilleri-vaimustust: „[---] „eile saadeti see [„Wilhelm Telli” eksemplar] ühele Hartmanni-nimelisele tudengile Riiast, kuid rõõmu tal sellest polnud, sest kõik jooksid talle tormi, kõik tahtsid temalt Telli laenata, kuid võitjaks osutusime mina ja mu toakaaslased, meie saime selle omanikult kätte! Eile õhtul niisiis, kui loengud olid läbi, kogunes meie juurde hulk tudengeid ja üks meist luges kõigile Telli ette. See valmistas meile tõelist rõõmu."” (Rauch 1994: 64-65)

Perekondliku ettelugemise võib jagada kahte ossa: esmalt loeti ette lastele, ja kui lapsed said suuremaks, hakkasid nemad teistele ette lugema. Vahel andsid ettelugemiseks põhjuse ka lähedaste tervisemured: lapsed õppisid hoolivust, lugedes ette pereliikmeile, kes seda ise teha ei saanud, ja lihvides samal ajal oma oskusi. Asjakohaseid näiteid võib leida kogu perioodi lõikes. Nii luges XIX sajandi algupoolel oma isale ette Emil Anders: „Minu isa, kes lasi mul endale oma nõrkade silmade pärast aasta otsa ette lugeda, harjutas mind ilmekalt esinema, mis tuli mulle väga kasuks. Secunda's pidin ma avalikul eksamil deklameerima Krõlovi tuntud vene valmi „Haned”." (Anders 2012: 27) Järvakandi mõisas sündinud kirjanik Otto von Taube (1879-1973) pidi aga harjutamise eesmärgil isale prantsuskeelseid raamatuid ette lugema (Taube 1944: 201). Tallinna poiss ja arsti poeg Hein Hoffmann (1920-2013) luges pärastlõunati ette vanaemale, kes viimastel eluaastatel jäi kae tõttu aegamööda pimedaks. Sel oli oma eellugu:

Kui ma kooli läksin, oli mul esimestes klassides suuri raskusi lugema õppimisega. Koolitunnistustel seisis kaks aastat järjest märkus: „Hein peab iga päev soravat lugemist harjutama.” Mu vanemad võtsid seda tõsiselt, sealjuures ka sõnu „iga päev”. Nii sai minust ettelugeja. Õhtuti istusime mõnusalt verandal, isa toppis paberosse ja mina lugesin ette. See pidi kuulajatele paras piin olema - kuulata mind pool tundi kogelemas ja puterdamas. Eriti hull oli lugu siis, kui pidin lugema alamsaksa keeles, sest mu isa hindas väga Fritz Reuteri ${ }^{11}$ teoseid [---]. Mu ainus lohutus oli, et mu sõbral Dieter Mickwitzil läks lugemine veel vaevalisemalt. (Hoffmann 1999: 111)

Lastele ettelugemise või nendega ühiselt lugemise kohta on näiteid ohtralt; säärane ettelugemine võis olla nii kaudne kui ka otsene. Kaudse ettelugemise puhul oli laste kaasamine suurte inimeste sekka märk nende kasvavast seltskonnakõlblikkusest: „[---] seni kuni päevavalgust jagus, määrati ühiselt kogutud putukaid ja lisati need kollektsioonile. Kui juba lampi tarvis läks, ei saadetud mind enam õdede juurde mängima, vaid jäeti täiskasvanute juurde. Uuriti teaduslikke teoseid või siis loeti, nagu varemgi, ühiselt luuletusi ette. Sellel talvel kuulsin ka, vanaisa [krahv Alexander Keyserling] poolt ette loe-

${ }^{11}$ Fritz Reuter (1810-1874), alamsaksa keeles kirjutanud saksa kirjamees, omal ajal väga populaarne ja ka baltlaste seas väga hinnatud. 
tuna, esimest näidendit, Schilleri „Röövleid”.” (Taube 1944: 192) Lastele otse ette lugemisel arutati aga läbi selle käigus tekkinud küsimused, nagu kirjutab Taube: lugedes J. H. Campe teost Ameerika avastamisest, ${ }^{12}$ võeti appi ka maakaart ja gloobus (Taube 1944: 162).

Ettelugemist haridusliku ja praktilise perekondliku ajaveetmise viisina on kirjeldanud jurist ja vabariigiaegne Saksa kultuuromavalitsuse sekretär, Tartus arsti perekonnas sündinud Oswald Hartge (1895-1976):

Kui me suuremaks saime, korraldas ema korra nädalas „mugavaid õhtuid”. Istusime siis tema buduaaris hubaselt laua ääres ning ta luges meile ette, sellal kui meie tohtisime meisterdada või joonistada. Veel tänagi mäletan selliseid raamatuid nagu de la Motte-Fouqué „Der Schweizer Robinson” [„Šveitsi Robinson”] ja „Zauberring” [„Võlusõrmus”] ${ }^{13}$, Otto Ludwigi „Die Heiteretei” [„Heiteretei”], ${ }^{14}$ Seideli „Leberecht Hühnchen”, ${ }^{15}$ Brentano „Hinkel, Gockel und Gackeleia” [„Hinkel, Gockel ja Gackeleia”] ${ }^{16}$. Hiljem lisandusid „Wilhelm Tell”, „Orleans’i neitsi”, „Hermann ja Dorothea”, „Dichtung und Wahrheit” [,Luule ja tõde”]17, „Odüsseia” ja teised klassikalised lood. Nõnda kirjeldatuna võib raamatute valik imestama panna. Jättes kõrvale selle, et olen unustanud mainida nii mõnegi raamatu, arvan sellegipoolest, et ema toimis väga suure pedagoogilise asjatundlikkusega, sest meie, lapsed, kuulasime meelsasti, rõõmustasime nende õhtute üle ja õppisime armastama raamatuid ja raamatute lugemist. Pealegi õppisin ma nendel õhtutel tundma nii mõndagi raamatut, mida ma kuni tänaseni pole unustanud. Siin oli oma tugev mõju idealistlikul põhihoiakul, mis mu emal loetu suhtes oli. Kuid ka praktiline elu ei jäänud kõrvale: lugemise ajal kudus ta katkematult lastele mustavärvilisi sukki. (Hartge 1968: 40)

Alati ei osanud lapsed aga loetusse vajaliku respektiga suhtuda, nagu seda meenutab hilisem diplomaat Berndt von Staden (1919-2014): „Lõputu kannatlikkusega luges ta [vanaema] meile, lastele, lasteraamatuid ette, „Winnetouga” alustades ja „Viimase mohikaanlasega” lõpetades. Mul on veel selgelt meeles Hector Malot' „Perekonnata” [,Sans famille”, liigutav lugu ühest vaeslapsest. Vanaema, kel olid silmad märja koha peal, ei suutnud nuuksumise tõttu edasi lugeda, mina aga, kuus või seitse aastat vana, olin vaibal naerust kõveras." (Staden 2004: 33)

${ }^{12}$ Saksa valgustaja ja pedagoogi Johann Heinrich Campe (1746-1818) noorsooromaan „Die Entdeckung von Amerika. Ein Unterhaltungsbuch für Kinder und junge Leute” (1781).

${ }^{13}$ Saksa romantilise kirjamehe Friedrich Heinrich Karl Baron de la Motte Fouqué (1777-1843) rüütliromaan „Zauberring” (1812), robinsonaadi „Der Schweizerische Robinson” (1812) autor peaks aga olema siiski Berliini linnapastor Johann David Wyss (1743-1818).

${ }^{14}$ Muusiku ja kirjaniku Otto Ludwigi (1813-1865) psühholoogiline jutustus „Die Heiteretei und ihr Widerspiel" (1857).

${ }^{15}$ Heinrich Seideli (1842-1906), saksa raudteeinseneri ja kirjamehe mitme teose peategelane.

${ }^{16}$ Heidelbergi romantismi keskse esindaja Clemens Brentano (1778-1842) muinasjutt, ilmunud aastal 1838 .

${ }^{17}$ Ilmselt on mõeldud Johann Wolfgang von Goethe (1749-1832) autobiograafiat „Aus meinem Leben. Dichtung und Wahrheit" (1811-1833). 


\section{Kus, kuidas ja mida loeti ning kuidas raamatuid saadi}

Kuna Baer kasvas lapsena kahes perekonnas, leiab tema meenutustes sissevaateid nii isa kui ka onu vaimsetesse harrastustesse, sealhulgas lugemisviisidesse. Tema onu oli mõnevõrra ekstsentriline sõjandushuviline, kes põllumajandust ja aiandust oli õppinud ex usu - tema kaunis piiratud raamatukogus leidus vaid üks entsüklopeedilise sisu ja loodusteadusliku kallakuga raamat, millest vajadusel teadmisi ammutati, kui noor Baer tuli koju mõne teo või kivistisega. Baeri praktilise meelelaadiga isa ${ }^{18}$ armastas samuti lugeda, kuid see oli tema jaoks vältimatu ajatäide, teatud määral ehk isegi sundkäitumine, lektüüri sisu polnud sealjuures ilmtingimata määrav:

Vaimutöövajadus tegi temast usina lugeja, nii et ta oli harjunud ka reisil olles või vankriga sõites pidevalt lugema, isegi kohvi keetmise ajal pidi lugema. Romaane luges ta üliharva, vahest ehk neid, millest väga palju räägiti, nagu omal ajal näiteks Walter Scotti teosed. Lugemisvara hõlmas peamiselt õpetlikku laadi kirjatöid, kuid mitte tõsise stuudiumi kombel, vaid nii nagu juhtus, pigem selleks, et mitte tegevuseta istuda, kui et loetut endale meelde jätta. Kui olin juba doktor, leidsin isa oma üllatuseks konversatsioonileksikoni viiendat väljaannet lugemas [---] Selline segapuder oleks mõne vähem kaine mõistuse ja praktilise meelega mehe pidanud omadega sassi ajama, isal aga aitas see vältida üksiolekuhetkede talumatut tegevusetust. (Baer 1865: 46-47)

Maal elades polnud raamatute hankimine siiski kerge, jätkuma pidi kodustest raamatutest ja koduõpetaja „väikesest, kuid mulle loomulikult suurena tunduvast raamatukogust" (Baer 1865: 34), sellest oli tingitud ka lektüüri juhuslikkus. Kui Baer aastal 1807 Tallinna toomkooli astus ja linna elama asus, laienes ka tema lektüüri valik ja kättesaadavus:

Mulle avaldasid väga soodsat mõju kaks asjaolu. Koduga võrreldes pakkusid kool ja linn mulle hoopis rohkem raamatuid. Eriti soodsalt mõjus see, et koolis oli meil sarnaste huvidega noorukite ring, mis innustas mind tegelema kirjandusega.

Mida rohkem koolist aega üle jäi, seda rohkem kasvas viimastel isakodus veedetud aastatel vajadus täiendava lugemisvara järele. Noorsooraamatuid oli meil üsna palju, aga pärast Campe reisikirjelduste, ${ }^{19}$ Ameerika avastamisloo ja lasteajakirjade ${ }^{20}$ lugemist neist enam ei piisanud. (Baer 2015: 73)

18 Johann Magnus von Baer (1765-1825), Piibe mõisa omanik, provintsiaalpoliitik, 1815-1818 Eestimaa rüütelkonna peamees.

${ }^{19}$ Johann Heinrich Campe noorsoole suunatud, kolmes jaos ilmunud (vastavalt 12, 6 ja 7 osa) reisikirjelduste kogu, mille esimese osa „Erste Sammlung merkwürdiger Reisebeschreibungen für die Jugend” ilmus Hamburgis aastal 1785, viimane aga Braunschweigis aastal 1806.

${ }^{20}$ Baeri mälestuste eestikeelne tõlge on siin ebatäpne. Originaalis leiduv väljend „igasugu „Lastesõprade järgede”" („allerlei „fortgesetzte Kinderfreunde””) (Baer 1865: 93) on tõlkes asendatud lihtsalt „lasteajakirjadega” (Baer 2015: 73). Originaal viitab aga esimesele saksa lasteajakirjale Der Kinderfreund (Laste Sõber), see ilmus aastatel 1775-1782 ja selle väljaandjaks oli saksa valgustusaja kirjamees ja pedagoog Christian Felix Weiße (17261804), keda koos Campega peetakse üheks saksa laste- ja noorsookirjanduse rajajaks. 
Tähelepanuväärne on siiski Baeri koduse lektüürivaliku kaasaegsus: lisaks moes olevale Scottile leidus ka saksa noorsookirjanduse ühe teerajaja Campe teoseid. Erinevate valdkondade teaduskirjandust leidus Baeri koduõpetajal, noor Baer otsis aga „ilusat kirjandust”, millest ta tundis vaid Schilleri luuletusi, vahel lisandus sellele laenuks saaduna mõni tema näidenditest (Baer 1865: 93). Baer tõdeb: „Uuemate saksa kirjanike teoste odavaid kogutud väljaandeid tollal veel polnud, ja kallihinnalisi vanemaid väljaandeid polnud meil kodus olemas, ja kui neid kusagil naabruskonnas leiduski, ei olnud need mulle eakaaslaste puududes ligipääsetavad. $\mathrm{Mu}$ isa raamatukogu sai hoolikalt läbi soritud, Corpus juris'e ja tollal veel ainult käsikirjas rüütli- ja maaõiguse panin aupaklikult kõrvale, jättes ükskõikselt kõrvale ka mõned põllumajandusalased teosed, „Hoolsad majaemandad”, hobusetohtrid ja muu taolise.” (Baer 1865: 93) „Hoolsate majaemandate” (,Sorgsame Hausmütter”) nime all võtab Baer kokku koka-, majapidamis- ja ravitsemisnõuandeid jagava kirjanduse (vrd nt Plath 2014), „hobusetohtrid” („Roßärzte”) on aga karja- ja hobuseravitsemise käsiraamatute üldistav mõiste. Sellise suures majapidamises igapäevaseks hakkamasaamiseks tarviliku kirjanduse valik sõlmib omalt poolt otsad kokku baltisaksa anekdootides esinevate jahi- jm praktilise elu käsiraamatutega.

Sarnaselt Baeri isaga harrastas ka Otto von Taube isaisa Otto Fromhold von Taube (1800-1873) lugemist vabas õhus - mõisa pargis pingil istudes, lugedes näiteks Cicerot originaalkeeles (Taube 1944: 52). Otto von Taube lapsepõlvelektüürist moodustasid kindla osa vendade Grimmide muinasjutud, mida kasutati pedagoogilistel eesmärkidel, et parandada laste saksa keelt. Lapsed pidid tunnis neile ette loetud muinasjutte ümber jutustama korrektses keeles: eestimaalaste poolt nii meelsasti allaneelatud sõnalõpud tuli kuuldavalt välja hääldada, vältida tuli mittesaksa väljendeid ega tohtinud rääkida eesti keele moodi artikleid kasutamata (Taube 1944: 163-164). Campe loomingut loeti veel ka XIX sajandi lõpus - nii sai Taube Ameerika avastamisloo ja Defoe Robinson Crusoe ümberjutustuse ${ }^{21} 1885$. aastal jõulukingiks. Siiski oli osa sellest oma laadilt vananenud ja Crusoe ümbertöötlusse pikitud pedagoogilise sihiga küsimused mõjusid tobedalt: „Ema hakkas mulle ette lugema, kuid ma keeldusin kuulamast, ärritatuna tekstile väljaandja poolt lisatud, nn väikese Lottcheni vaheküsimustest. Kuna mu isa pidas neid küsimusi samuti tobedateks, sain sellest tuge ja saavutasin, et Robinson läks kappi tagasi." (Taube 1944: 162) Taube puhul käis kirjandusega tutvumine, eakohasust silmas pidades, vanemliku järelevalve all: „Samettoas [---] seisis väike raamatukapp, millel oli alati võti ees. Selles kapis oli teos „Der neue Plutarch” [„Uus Plutarchos"] ${ }^{22}$, ilmunud Viinis 1858, mis sisaldas kuulsate meeste lühikesi elulugusid ühes piltidega. Selle raamatu lugemine oli minu kirg, siiski ei soovinud mu vanemad, et ma seda raamatut ilma nendeta vaataks. Enamasti olin ma ju kuulekas, kuid kui ma mängides vahel üksi tuppa jäin, sai kiusatus minust võitu: tõin raamatu lagedale, lõin selle lahti ja lugesin - ühe kõrvaga

${ }^{21}$ J. H. Campe, „Robinson der Jüngere zur angenehmen und nützlichen Unterhaltung für Kinder" (1779/1780).

${ }^{22}$ August Diezmann, „Neuer Plutarch oder Biographien und Bildnisse der berühmtesten Männer und Frauen aller Nationen und Stände" (Wien-Leipzig: Hartleben, 1858). 
kuulatades, ega keegi ei tule, et siis raamat, niipea kui kuuldub midagi kahtlast, ruttu tagasi panna." (Taube 1944: 166)

Vanemate süsteemset lähenemist laste lektüürivaliku kujundamisele kirjeldab XIX sajandi lõpul sündinud Hartge. Isa põhimõtetest lähtuvalt oli poegade tuba sisustatud spartalikult, kuid raamatuid oli palju, „sest ema tavatses meile jõuludeks ja sünnipäevadeks kinkida raamatuid, tehes seda ka muul ajal, pannes raamatu suurt juttu tegemata lihtsalt riiulisse. Ta ehitas meie raamatukogu süstemaatiliselt üles. Esmalt erinevate ajastute noorsooromaanid, nt Höckeri noorsooraamatud ${ }^{23}$, „Sigismund Rüstig”24, „Robinson Crusoe”, „Till Eulenspiegel”, „Nahksuka jutud”. Neile esimestele ise lugemiseks mõeldud raamatutele järgnesid kreeka ja saksa legendid ja muinasjutud ning palju muud. Ta ei sundinud kunagi ühtegi raamatut lugema. Need olid aga vihmase ilmaga käeulatuses ja nõnda loeti neid meelsamini kui agara vanemliku manitsuse saatel." (Hartge 1968: 39-40)

Ohtralt raamatuid leidus Taube kaasaegse Carl Hunniuse kodus, kes pidas neist ka lugu: „Olin suur lugeja. Vabal ajal neelasin raamatuid, eelkõige ajaloolisi romaane. Secunda ja prima õpilasena lugesin ma vahel öö otsa ja läksin magamata kooli. Mu tulemused koolis halvenesid loomulikult silmanähtavalt”. (Hunnius 1985: 39) Hunniuse lektüüri moodustasid ajaloolised romaanid toonastelt populaarsetelt autoritelt, nagu Dahn ${ }^{25}$, Wolf ${ }^{26}$, Ebers ${ }^{27}$, Samarg $^{28}$, Echstein ${ }^{29}$. Veel luges ta Schilleri draamasid ja Shakespeare'i ajaloolisi näidendeid, samuti romantismiperioodi ja Noor-Saksamaa autorite ajalooainelisi teoseid, Tiecki ${ }^{30}$ novelle, aga ka ajalooraamatuid, nagu Freytagi „Die Ahnen” („Esivanemad”), „Bilder aus deutscher Vergangenheit”31 („Pilte Saksa ajaloost”) või Onckeni „Allgemeine Geschichte in Einzeldarstellungen”32 („Üldajalugu üksikkäsitlustes”). Kaevumine keskaega sai tõuget kaasajast: „Oli aasta, mil Tallinn hakkas venestuse sunni all oma välist kuube muutma. [---] Suure kirega kujutasin ennast tagasi aegadesse, kui siin valitses Saksa ordu." (Hunnius 1985: 30-31) Ajaloolisi romaane luges kooliajal ka Taube ja Hunniusega enam-vähem kaasaegne, tulevane Eestimaa rüütelkonna sekre-

${ }^{23}$ Ilmselt saksa noorsookirjanik Oskar Höcker (1840-1894).

${ }^{24}$ Inglise mereväeohvitser ja kirjanik Frederick Marryat (1792-1848), kelle teos „Masterman Ready, or the Wreck in the Pacific" (1841) ilmus saksa keeles pealkirja „Sigismund Rüstig” all.

${ }^{25}$ Felix Dahn (1834-1912), juuraprofessor, ajaloolane ja ajalooliste romaanide autor.

${ }^{26}$ Julius Wolff (1834-1910), ajakirjanik ja ajalooliste luuletuste ning romaanide autor.

${ }^{27}$ Georg Moritz Ebers (1837-1898), egüptoloog ja arvukate ajalooliste ning populaarteaduslike raamatute autor.

${ }^{28}$ Ilmselt autori trükiviga, tegu võiks olla Gregor Samarowiga (kodanikunimega Johann Ferdinand Martin Oskar Meding, 1829-1903), peamiselt oma kaasaegseid poliitika- ja diplomaatiasaladusi ning Venemaad käsitlenud seiklusromaanide autoriga.

${ }^{29}$ Samuti ilmselt trükiviga, tegu võiks olla ajalooliste romaanide autori Ernst Ecksteiniga (1845-1900), kes tegi koostööd ka Felix Dahniga.

${ }^{30}$ Saksa romantismi üks rajaja Johann Ludwig Tieck (1773-1853).

${ }^{31}$ Gustav Freytagi (1816-1895) kuueköiteline sari „Die Ahnen” (1872-1880), mis käsitleb ajaloo kulgu ühe perekonna näitel, antud juhul siis germaani-saksa ajalugu alates suurest rahvasterändamisest kuni Saksa keisririigi loomiseni, ja neljaosaline „Bilder aus deutscher Vergangenheit” (1859-1867), mis käsitleb samamoodi Saksa ajalugu alates germaanlastest.

${ }^{32}$ Saksa ajaloolase Wilhelm Onckeni (1838-1905) 44-köiteline koguteos. Oncken sai laialt kuulsaks populaarteaduslike ettekannetega. 
tär Eduard von Stackelberg (1867-1943), temal täitsid need ka lünkliku ajalookäsitluse täitematerjali rolli:

Saksa keele tunnis hoiti meist eemal kõik ebasünnis ja kahtlane. Salaja luges enamik meist Zolad ja tõelist sopakirjandust, kohustuslikud vene autorid mu kaaslasi aga ei tõmmanud. Tunnistan, et lugesin Tolstoid siiski ahnelt, sest enne seda olin lugenud saksa keeles odavaid juturaamatuid - lugematul hulgal Spielhagenit ${ }^{33}$ ja Gregor Samarowit. Neile lobisemishimulistele jutustajatele olen ma tänu võlgu vähemalt teatud sissejuhatuse eest uuemasse ajalukku, mis muidu oli meile ju täiesti ligipääsmatu. Siis lugesin ma veel Ebersit ja Dahni, Karl Vogti ${ }^{34}$ ja Büchnerit („Jõud ja ollus”) ${ }^{35}$, Heinrich Heinet ja David Straussi ${ }^{36}$, aga ka midagi paremat: Cooperi Nahksuka jutte, Bulwerit ${ }^{37}$ ja Kierkegaardi. Selline puudujääk nooruse lugemisvajaduse mõjutamises oli tollase kasvatuse suurim viga. (Stackelberg 2010: 25)

Stackelberg leidis, et kuigi koolisüsteemis on tehtud muudatusi, loeb tema mälestuste kirjutamise kaasaegne, 1920. aastate noorsugu oluliselt vähem kui tema põlvkonnakaaslased omal ajal: „Tänapäeva kool pakub rohkem, saavutab aga ilmselt vähem, sest kindlasti ei loeta enam nii palju kui varem - seda tänu angloameerika spordimaaniale" (Stackelberg 2010: 25). 1920. aastate noorsugu esindav, Tallinnas pastori perekonnas kasvanud Ingeborg Kentmann (1916-1989) õppis lugema ja kirjandust hindama Hans Christian Anderseni loomingu varal:

$\mathrm{Mu}$ esimene kokkupuude raamatutega jääb sõjajärgsesse aega, kui ma veel lugeda ei osanud. See oli silmatorkamatu tumepunaste kaantega õhuke raamatuke, millest ma endale ikka ja jälle ette lugeda lasin - Anderseni muinasjutt „Lumekuninganna”. [---] Mida rohkem ma Anderseni tundma õppisin, seda enam ta mulle meeldima hakkas ja ehk andis varane kokkupuude selle autoriga mulle oskuse „õiget” ära tunda ja hoidis mind „tehtu” heamaitseliseks pidamise eest. (Kentmann 1980: 81-82)

Kentmanni mälestustes on lugemisele pühendatud eraldi peatükk, lisaks Andersenile nimetab ta mitmeid teisi lemmikuid, nagu näiteks Ågot Gjems Selmeri ${ }^{38}$ romaani „Die Doktorsfamilie im Hohen Norden” („Tohtripere kaugel põhjas”): „Kuidas ma sellele perekonnale kaasa elasin! [---] Meie balti talv oli piisavalt pikk ja pime, et lasta mul ette kujutada, mida tähendas elada kuude kaupa ilma eluandva valguseta.” Või Agnes Sapperi ${ }^{39}$ „Die Familie Pfäffling”

${ }^{33}$ Friedrich Spielhagen (1829-1911), saksa XIX sajandi populaarsemaid romaanikirjanikke.

${ }^{34}$ August Christoph Carl Vogt (1817-1895), loodusteadlane ja poliitik, evolutsiooniteooria pooldaja.

${ }^{35}$ Friedrich Karl Christian Ludwig Büchner (1824-1899), arst, loodusteadlane ja filosoof.

${ }^{36}$ David Friedrich Strauß (1808-1874), teoloog, filosoof ja kirjanik.

${ }^{37}$ Edward George Bulwer-Lytton (1803-1873), inglise poliitik ja kirjanik. Tema tuntuim teos on „Pompeji viimased päevad” (1834).

${ }^{38}$ Norra näitleja ja kirjanik Ågot Gjems Selmer (1858-1926).

${ }^{39}$ Saksa populaarne noorsookirjanik, elas aastatel 1852-1929. Kõnealune romaan, ilmunud 1907, oli tema tuntuim teos, mille kogutiraaž oli pea miljon eksemplari. 
[„Perekond Pfäffling”], mida sai „kuni pähekulumiseni” loetud, ja Mark Twaini „Tom Sawyer” ning „Prints ja kerjus”. Samuti luges ta suure kaasaelamisega ballaade: „mida kurvem ja hirmsam, seda ilusam”, eriti võluv oli Bürgeri „Lenore". ${ }^{40}$ Suure lugemise äramärkimiseks kinkis vend Ingeborgile hambapesutopsi jaoks eraldi aluse, et õde „ette kummardudes hambaid pestes, silmad samal ajal raamatut neelamas”, mööblit ära ei rikuks (Kentmann 1980: 82-83).

Kui Carl Hunnius kasutas pealetükkiva venestusega seoses ajalooromaane ja ajalookirjandust siseemigratsiooniks, siis vahel tuli ette ka kirjanduse ja reaalsuse põrkumist. Ideoloogilises mõttes võib pidada kõige süütumaks Oswald Hartge emaga juhtunut: olles eelmise sajandivahetuse paiku populaarseks saanud Sherlock Holmesi kriminullide kütkes, peletas ta ukse tagant väga reljeefselt minema uue, venelasest professori, kes oli saabunud hilisel tunnil ta arstist abikaasale viisakusvisiiti tegema (Hartge 1968: 32-33).

Maailmavaated põrkusid aga Berndt von Stadeni puhul, kes värskelt kirjandusest ammutatud ajalooteadmisi oma sugulastele tutvustas. Staden veetis lapse- ja noorpõlve Tallinnas, külastas aga aastal 1930 Schwerinis sugulasi, kes olid 1919. aastal punase terrori eest Saksamaale põgenenud:

Õnnetu juhuse tahtel olin just enne oma esimest külaskäiku lugenud ühe Girgensohni-nimelise ${ }^{41}$ balti naisautori lasteraamatut „Ilo, Kaupo poeg ja Hans von Tiesenhusen". Raamat kirjeldab, kuidas saksa Mõõgavendade ordu ja selle vasallid vallutasid vana Liivimaa, kusjuures autor ei püüagi varjata oma sümpaatiat liivlaste, praeguseks juba peaaegu väljasurnud hõimu vastu, kes on suguluses eestlastega. Täidetud sedasorti teadmistega, rabasin ma vanu häid aegu meenutanud perekonnaringi jahmatamapaneva teatega, et mõisate võõrandamine oli ju tegelikult vaid õigluse jaluleseadmise akt. (Staden 2004: 35)

Õnneks otseseid repressioone ei järgnenud, küll aga manitseti noore lugemishuvilise ema.

Sarnast, kuigi ideoloogiliselt vastupidi laetud kirjanduse mõju meenutab Stadeni kaasaegne ja -linlane Hein Hoffmann:

Me lugesime palju sõjakirjandust, alustades saksa kangelaslugudega ning tipnedes raamatutega nagu „In Stahlgewittern” [„Terastormis”], ${ }^{42}$ mis ülistas sõda ja saksa sõdureid. Sõja lõppu ühes revolutsiooniga 9.11.1918 ning keiser Wilhelmi troonist loobumist kujutati meile kui kodumaa reetmist [---] Lugesime raamatut „Im Felde unbesiegt” [„Sõjaväljal võitmatu”], ${ }^{43}$ kus kujutati olukorda rindel aastal 1918 nii valesti, justkui oleks Saksamaa veel võinud sõja

${ }^{40}$ Gottfried August Bürgeri „Lenore” (1744), üks tuntumaid ballaade saksa kirjandusloos.

${ }^{41}$ Lotta (Charlotte) Girgensohni (1869-1941) Riia linna asutamise 700. aastapäevaks 1901. aastal ilmunud romaan „Ylo, Kaupos Sohn und Hans von Tiesenhusen. Erzählung aus der Zeit von Rigas Gründung für die reifere Jugend. Eine Festgabe zum 700-jährigen Jubiläum der Gründung der Stadt Riga: 1201-1901”.

${ }^{42}$ Saksa ohvitseri ja kirjaniku Ernst Jüngeri mälestused Esimesest maailmasõjast, mis ilmusid aastal 1920.

${ }^{43}$ „Im Felde unbesiegt. Der Weltkrieg in 28 Einzeldarstellungen”, välja antud Münchenis aastal 1921. 
võita. Nii kujunes ka minus, kes ma olin ju alles pärast sõda sündinud, välja tugev saksa patriotism, mida süvendasid järgnevad repressioonid ja vaenamine eestlaste poolt, kelle suhtes me olime vähemuses ja seega kehvas positsioonis. See oli „militaarne” patriotism. Patsifism oli sõimusõna. Raamatuid, mis ei kujutanud sõda ülistavalt, nagu „Läänerindel muutuseta”, korralik sakslane ei lugenud. (Hoffmann 1999: 9)

Eesti poolelt kirjeldab sarnast suhtumist oma mälestustes temast paarkümmend aastat vanem Helmi Mäelo, kes oma kooliaegsest lektüürist oli jällegi küllaga saksaviha ammutanud (Mäelo 1974: 54). Latentset frankofoobiat kirjeldab Staden:

Vanaisakodu rõõmude hulka kuulusid mu varakult surnud onu Roberti nooruspõlve raamatud. Ma olin juba üheksa- või kümneaastaselt päris paras raamatukoi. Nendest raamatutest kaks on mul eriti hästi meeles. Ühe pealkiri oli „Deutsche Treue, welsche Tücke” ('Saksa truudus, prantsuse salakavalus') ja see käsitles Saksa-Prantsuse sõda aastail 1870-1871. Kaanel kujutati Saksa tragunit võitlemas Prantsuse raskeratsaväelasega, kusjuures loomulikult oli selgelt näha, kelle poole võit kaldub. Teise raamatu pealkiri oli „Pieter Marits"44 ja see kirjeldas buuride kangelaslikku võitlust „salakavala Albioni” [---] vastu. (Staden 2004: 43)

Lektüüri valikut piiras ja määras XVIII sajandi lõpul ja XIX sajandi algul ka raamatute kättesaadavus. Lisaks eespool kirjeldatud teostele leiab Baer kodusest raamatukogust „mõnede ladina ja inglise krestomaatiate ja sõnaraamatute” kõrval siiski „vaid vähe saksa kirjandust, seegi natuke vananenud". Kuna sobilikku kirjandust oli vähe, rakendus tema puhul intensiivse lugemise strateegia: „Gellerti ${ }^{45}$ valme teadsime juba ammuilma, tema teised teosed aga enam ei istunud. Hagedorn ${ }^{46}$ ja muu sarnane kraam veelgi vähem. Seetõttu loeti seda, mis meeldis, seda korduvamalt. Leidsin väikese saksa kirjanduse krestomaatia, milles leidus Blumaueri Aenease-travestia ${ }^{47}$ teine osa. Seda lugesin ma korduvalt ja varsti oli see mul täiesti peas.” (Baer 1865: 93)

Maakohtadega võrreldes oli olukord veidi parem linnas, seda just laiema raamatuid omavate isikute ringi poolest: „Koolis oli nälga saksakeelse kirjanduse järele hoopis hõlpsam leevendada. Enamikul õpilastest leidus üht-teist ja hulga peale kokku oli seda kaunis palju." (Baer 1865: 94) Tallinnas, kus 1802. aasta seisuga oli koguni kaks raamatukauplust (Reimo 2001: 215), leidus ka võimalusi raamatute tagavara suurendamiseks, andes tõuke Baeri „bibliomaansete kalduvuste” avaldumiseks.

${ }^{44}$ Saksa kirjamehe August Wilhelm Otto Niemanni (1839-1919) 1885. aastal ilmunud romaan „Pieter Marits, der Burensohn von Transvaal”.

${ }^{45}$ Ilmselt Christian Fürchtegott Gellert (1715-1769), saksa moraliseeriv valgustaja ja omal ajal väga populaarne kirjamees, lustmängude ja valmide autor. Eesti keeles ilmus tema moraliseeriv teos „Wallelik pois ja temma issa” aastal 1806.

${ }^{46}$ Friedrich von Hagedorn (1708-1754), rokokooajastu luuletaja, kirjutas ka valme.

${ }^{47}$ Austria kirjamehe ning ajakirjaniku Aloys Blumaueri (1755-1798) 1784. aastal ilmunud travestia Vergiliuse eeposest „Aeneis”, mis sai vaimustatud vastuvõtu osaliseks ja tõlgiti teistesse keeltesse. 
Lisaks raamatukaupmeestele ja trükkalitele olid levinud raamatuvahendamise mooduseks toona raamatuoksjonid, kus müüdi linnakodanike pärandvara (Reimo 2001: 214-215; Pullat 2016: 252-279). Baer kirjeldab suure kaasaelamisega 1807. aastal toimunud toomkooli endise direktori J. Chr. Tideböhli eraraamatukogu oksjonit, mis toimus paar kuud pärast Baeri toomkooli astumist: „Raamatuoksjon on alati omaette sündmuseks linnas, mis asub kaugel raamatukauplemise keskmest, kuid kus siiski tuntakse vajadust raamatute järele" (Baer 1865: 94). Võrdluseks võib tuua saksa reisikirjamehe J. G. Kohli kirjelduse raamatukaubanduse oludest Tartus, kus XIX sajandi esimestel kümnenditel toimis raamatute müük sarnastel alustel: raamatutega tegeles üks kaupmees, kes hankis oma kaupa oksjonitelt ja müüs seni, kuni ladu tühi ja uus oksjon silmapiiril; „raamatut, mida sooviti, ei otsitud ja tellimusi raamatutele välismaalt vastu ei võetud”. Kohli Balti kubermangude reisi ajaks (1837) oli olukord paranenud, raamatukaupmehi oli Tartus juba kolm, ehkki Kohli sõnul oli seda „muidugi küllalt vähe”, siiski oli nüüd „üliõpilastel järjest lihtsam end raamatutega varustada ja Tartu kolm raamatukauplust ei jäta elegantsi jms poolest tõepoolest midagi soovida”, kuigi „professorid, kes oma nimel võivad välismaalt tellida, mida nad soovivad, enamasti kõik otse Saksamaalt tellivad”. Kohl kiidab ka raamatukaupmeeste vastutulelikkust, kes „nüüd igale raamatule hinnaalandust teevad, kuna kümne aasta eest tehti seda vaid 100-taalrise arve korral”. (Kohl 1841: 265-266)

Tallinnas oli huvi Tideböhli raamatute vastu suur: „Esimestel päevadel oli oksjoniruum nii rahvast täis, et tagasihoidlik koolipoiss ei pääsenud raamatuid isegi vaatama; kolmandal päeval oli oksjoniruum juba niipalju tühjem, et ma võtsin vapralt sisse koha võistlejate hulgas" (Baer 1865: 94). Nooruk sattus hoogu, ostes esmalt Benjamin Hederichi (1675-1748) „Lexicon manuale Latino-Germanicumi”, millest sai talle „truu vademecum läbi terve elu”, siis aga ühe araabiakeelse raamatu, sest ta „polnud ühtegi araabiakeelset raamatut varem näinud", ja lõpuks ühe suure köitmata konvoluudi, mille keele kohta ei osanud keegi kohalolijaist midagi öelda. Hiljem selgus, et tegu oli taani- ja islandikeelse Islandi saagade kogumikuga. Lisandusid veel Christian Wolffi (1679-1754) neljaköiteline teos matemaatika alustest „Die Anfangs-Gründe aller mathematischen Wissenschaften”, tulevase arstiteadlasena huvitasid Baeri ka Richard Meadi „Monita et praecepta Media” (1751) ja veel üht-teist. Nagu ta ise resümeeris: „Oleksin pidanud juba siis mõistma, et varanduseks on vaid need raamatud, mida läheb tarvis, need aga, mida tarvis pole, on vaid koormaks. Kahjuks jõudsin säärasele arusaamisele alles kaunis hilja ja selle praktilisele elluviimisele õigupoolest veel üldse mitte.” (Baer 1865: 94)

Suur lugeja oli ka Baerist ligi kolm aastakümmet noorem Schwartz, kel oli aga Miitavis lugemisvara omast käest võtta koduse laenuraamatukogu näol, mida kingsepast isa pidas kõrvalteenistuse saamiseks. Lugemise äsja selgeks saanud kuueaastasele Schwartzile jätsid sügava mulje „pühad evangeeliumid” ja Goethe „Fausti” esimene osa. Lugemishimule seadis mõistlikud piirid asjaolu, et „õnneks ei olnud kodune raamatuvaru esialgu veel liialt suur” (Schwartz 2007: 15).

1873. aastal sündinud Hunniuse lapsepõlvekodus Mahu kirikumõisas oli „pidevalt raamatuid ühest kirjandusühingust”, kust liikmetele raamatuid välja laenutati. Oletatavasti oli tegu Eestimaa Kirjanduse Ühingu raamatu- 
koguga. Tallinna kooliaastatel oligi Hunniuse ülesandeks raamatute raamatukogust koju toomine-viimine, lisaks tarvitas ta oma lugemisnälja vaigistamiseks Kluge ja Ströhmi kirjastuse tasulist laenuraamatukogu, „niivõrd kui rahaline seis seda lubas". Välja kujunes ka huvi keskaja vastu ja 1889. aasta suvel luges ta läbi kõik Giesebrechti Saksa keisrite ajaloo ${ }^{48}$ köited, mille Tartus ülikoolis õppiv vend talle kaasa tõi (Hunnius 1985: 30).

Üliõpilaste jaoks oli eeldatavasti põhiliseks raamatuteni jõudmise kohaks Tartu ülikooli raamatukogu, ent vähemalt viimase sajandivahetuse paiku pakkusid ametlikule raamatukogule tugevat konkurentsi korporatsioonide raamatukogud, mis võimaldasid lugemist küll vaid liikmetele.

1893. aastal korporatsiooni Estonia astunud Hunniuse rebaseajal toimus sealse raamatukogu ümberkorraldamine, mille juures rebased iga päev mitu tundi aitama pidid (Hunnius 1985: 44). Selle käigus avastas Hunnius raamatukogust Nietzsche teosed, „mis tookord olid veel kaunis tundmatud”, ja tegeles - rebasena konvendis valves olles ja seetõttu seal ööbides - hommikutundidel enne magama jäämist Nietzsche-lektüüriga, mis „küll avaldas muljet, kuid puudus aeg süvenemiseks” (Hunnius 1985: 44). Korporatsioonis pidas ta raamatukoguhoidja ametit. Tema kohustuste hulka kuulus raamatukogu täiendamine, selleks saatsid raamatukaupmehed palju uudisteoseid tutvumiseks, mistõttu suure osa Hunniuse ajast täitis lektüür raamatukogu jaoks: „Mulle meeldisid norralased Ibsen, Björnson, Kjelland ${ }^{49}$ jt, õppisin tundma Sudermanni ja Hauptmanni ${ }^{50}$ ning teisi uuemaid saksa romaanikirjanikke" (Hunnius 1985: 48).

Frater rigensis Hartge, kes astus ülikooli ja korporatsiooni ilmasõja eel, mainib organisatsiooni raamatukogu, kus tema rebaseajal oli ca 30000 köidet. Suur oli saksa kirjanduse osakaal. Fraternitas Rigensises tegeles raamatukogu täiendamisega eraldi komisjon, mis koosnes tegevkonvendi ja vilistlaskogu liikmetest: „Seal oli kindlasti ka väärtusetut kraami, kuid suuremalt jaolt oli tegu asjatundjate või asja vastu huvi tundjate käe all aegamööda kasvanud koguga, kus ei leidunud mitte ainult suur, vaid ka mitmekülgne valik teoseid, sealhulgas koguni mõned esiktrükid, mis tänasel päeval oleksid üsna väärtuslikud. [---] Muuhulgas oli seal terve kapitäis kaasaegset sulesõda Wagneri poolt ja vastu." (Hartge 1968: 246-247)

Hartge lõpetab oma raamatukoguteemalised mõttearendused järgmiselt:

Lugesin konvendi lugemistoas pea iga päev ajakirju ja ajalehti ning laenasin raamatukogust nii mõnegi raamatu, sealjuures polnud enamasti kahjuks tegu õigusteaduslike, vaid pigem ajalooalaste asjadega. Lisaks lugesin ka 19. sajandi teise poole romaane, mille üle konvendis ôhtuti palju diskuteeriti. Olen ikka veel arvamusel, et ma neist vestlustest ja vabast lektüürist nondel aastatel rohkem õppisin kui ülikoolis loengutel käies. Küll mitte ülikooli, kuid elu jaoks kindlasti. (Hartge 1968: 247)

${ }^{48}$ Saksa ajaloolase ja Leopold Ranke kaastöölise Wilhelm von Giesebrechti (1814-1889) kuueköiteline sari „Geschichte der deutschen Kaiserzeit” (1855-1895).

${ }^{49}$ Norra XIX sajandi kirjanduse kolm suurt autorit Henrik Ibsen (1828-1906), Bjørnstjerne Martinius Bjørnson (1832-1910) ja Alexander Lange Kielland (1849-1906).

${ }^{50}$ Saksa naturalismi esindajad Hermann Sudermann (1857-1928) ja Gerhart Hauptmann (1862-1946). 


\section{Lõpetuseks}

Lugemine ja raamatud on baltisaksa memuaristikas sage teema. Seda ei esine muidugi absoluutselt kõigil autoritel, kuid vaatlusaluse küllaltki pika ajajärgu, eri seisustesse ja sugudesse kuuluvate autorite puhul võib esile tõsta asjaolu, et lugemist ja raamatuid on peetud memuaarides käsitlemise vääriliseks, veelgi enam: neid käsitletakse olulise osana isiksuse kujunemisel. Enim on juttu noorpõlve lugemiselamustest, ühelt poolt võib seda proovida seletada memuaaridele üldomase tendentsiga kirjeldada nimetatud eluetappi põhjalikumalt kui hilisemat aega, teisalt aga oli lugemine ka hilisemas elujärgus piisavalt tavaline, et seda oleks tarvitsenud kuidagi eriliselt esile tõsta. Täiskasvanuea lugemisharjumuse olemasolu tõendavad lisaks otsestele kirjeldustele ka kaudsed näited: lastele ettelugemine, pereringis ettelugemine, vanemaealistele pereliikmetele ettelugemine - kõik osana teatud biidermeierlikust baltisaksa perekondlikkusest. XIX sajandi teisest poolest alates võib märgata ka laste lektüürivaliku teadlikumat suunamist, samuti koduse raamatuvara kasvu, mida soodustasid paranenud kirjastus- ja raamatukauplemisolud, mööda ei saa vaadata ka üldisemast majandusliku järje paranemisest Balti kubermangudes. Olulised on organisatsioonide raamatukogud - antud näidetes korporatsiooniraamatukogud, kuid samamoodi ka muud klubilised asutused, mille eesmärgiks oli oma liikmete arendamine ja seltskondlik ajaveetmine.

Käsitletud tekstides mainitud autorid ja teosed näitavad pidevat, Saksamaaga samas taktis toimunud kultuuritarbimist ja Euroopa - eelkõige läbi Saksa prisma vahendatuna - moodsate ja aktuaalsete tekstidega kursisolekut, millele lisanduvad ka mõned kohalikud autorid. Lastele ettelugemine ja nende lugema suunamine, lektüüri kättesaadavaks tegemine käis inimea vaates esialgu pereliikmete vahendusel - esile tuleb siinkohal tõsta seisustest sõltumatut ema rolli laste lugema õpetamisel -, kasvades lisandusid ka sõbrad, kõrvalisem oli kooliprogrammi mõju. Oluline oli pereliikmete eeskuju, raamatute käepärasus, kuid ka isiklik huvi lugemise vastu. Laste sihipärane arendamine lugemise kaudu toimus loomulikul moel ja moodsalt öeldes „lõimivalt”, muude tegevuste taustal või kaudu. Muidugi puudusid tollal ka alternatiivsed ja passiivsed võimalused ajaveetmiseks ja meelelahutuseks.

\section{Kirjandus}

An d e r s, Emil 1892. Erinnerungen des weil. Universitäts-Bibliothekars zu Dorpat Emil Anders nebst einer Biographie und Charakteristik des Verfassers. Hg. von Leopold von Schroeder. Reval: Lindfors' Erben.

Anders, Emil 2012. Tartu ülikooli raamatukogu kunagise bibliotekaari Emil Andersi mälestused. Tlk Aira Võsa. Tartu: Tartu Linnamuuseum.

B a er, Karl Ernst von 1865. Nachrichten über Leben und Schriften des Herrn Geheimrathes Dr. Karl Ernst v. Baer, mitgetheilt von ihm selbst. Veröffentlicht bei Gelegenheit seines fünfzigjährigen Doctor-jubiläums am 25. August 1864 von der Ritterschaft Estlands. St. Petersburg: Buchdruckerei der Kaiserlichen Akademie der Wissenschaften. 
B a e r, Karl Ernst von 2015. Teateid härra salanõuniku dr. Karl Ernst von Baeri elu ja kirjatööde kohta edastatud tema enda poolt. (Ajajõe tagant.) Tlk Anti Lääts. Tartu: Ilmamaa.

B a r a n ow, Agnes 1941. Mein Baltenland. Erinnerungen. Stuttgart: J. F. Steinkopf. B ender, Reet 2017. Mõnda baltisaksa elulugudest ja mis seal sees leida võib. Elulood žanripiiridel. Keel ja Kirjandus, nr 8-9, lk 600-616.

B odisc o, Theophile von 1997. Versunkene Welten. Erinnerungen einer estländischen Dame. Weissenhorn: Anton H. Konrad.

B oeh m, Max Hildebert 1958. Die Balten als mündliche Menschen. Sonderdruck aus: Jahrbuch des baltischen Deutschtums 1958. Lüneburg: Carl-SchirrenGesellschaft.

Boetticher, Manfred von 2016. Zur Geschichte der Deutschbalten: zwischen den Welten. - Ineta Balode, Dzintra Lele-Rozentāle, Deutsch im Baltikum. Eine annotierte Forschungsbibliographie. Unter Mitwirkung von Manfred von Boetticher und Reet Bender. (Fremdsprachen in Geschichte und Gegenwart 17.) Wiesbaden: Harrassowitz, lk 15-36.

B u x h o ev e d e n, Ingeborg 1990. Sommer und Winter. Lebenserinnerungen 19201953. Köln: Wissenschaft und Politik.

Hartge, Oswald 1968. Auf des Lebens großer Waage. Erinnerungen 1895-1939. Hannover-Döhren: Hirschheydt.

H offm a n n, Hein 1999. Meine Kindheit und Jugend. Erinnerungen eines Estländers 1920-1945. Wedemark-Elze: Harro von Hirschheydt.

Hueck-Dehio, Else 1955. Liebe Renata. Geschichte einer Jugend. Heilbronn: Salzer.

H u e ck - Deh i o, Else 2001. Kallis Renata. Ühe nooruse lugu. Tlk Pille Toompere. Tallinn: Eesti Raamat.

Hunnius, Carl 1985. Meine Erinnerungen. (Historia Academica. Schriftenreihe des Coburger Convents, Heft 14.) Stuttgart: Studentengeschichtliche Vereinigung des Coburger Convents.

Kent m a n n, Ingeborg 1980. Eine Atempause lang. Kindheit und Jugend im Baltikum zwischen zwei Weltkriegen. Freiburg: Herder.

Kohl, Johann Georg 1841. Die deutsch-russischen Ostseeprovinzen oder Naturund Völkerleben in Kur-, Liv-, und Esthland. Kd I. Dresden.

Kra us, Wolfgang 1941. Die baltische Plaudertasche. Stuttgart: Franck'sche Verlagshandlung.

Kr u sen stjer n, Leonhard von 1979. Erinnerungen. Aalen: A. von Krusenstjern. Leppik, Lea 2001. Rektor Ewers. Tartu: Eesti Ajalooarhiiv.

Lind en berg, Nita 1986. Zauberkraft Erinnerung. Biographische Skizzen einer Baltin. Stuttgart: Urachhaus.

Lukas, Liina 2006. Baltisaksa kirjandusväli 1890-1918. (Collegium litterarum 20.) Tartu-Tallinn: Underi ja Tuglase Kirjanduskeskus, Tartu Ülikooli kirjanduse ja rahvaluule osakond.

Mäel o, Helmi 1974. Võõrsil. Mälestusi, vaatlusi, elamusi. Lund: Eesti Kirjanike Kooperatiiv.

Oettingen, Georg von 1926. Erinnerungen. - Baltische Lebenserinnerungen. Koost Alexander Eggers. Heilbronn: Eugen Salzer-Verlag, lk 129-168.

O s tw ald, Wilhelm 1926. Lebenslinien. Eine Selbstbiographie. Erster Teil. RigaDorpat-Riga 1853-1898. Berlin: Klasing. 
Pabst, Ernst 1998. Der baltische Literatenstand. - Jahrbuch des baltischen Deutschtums 1999. Hg. von der Carl-Schirren-Gesellschaft im Auftrag der DeutschBaltischen Landsmannschaft. Lüneburg-München: Schriftenvertrieb der CarlSchirren-Gesellschaft, lk 122-138.

Plath, Ulrike 2011. Emad, ammed ja korsetid: Balti naised biidermeieri ajal. Balti biidermeier. Panoraame ja lähivaatlusi. (Eesti Kunstimuuseumi toimetised 1. (6.)) Tallinn: Eesti Kunstimuuseum, Kadrioru Kunstimuuseum, lk 153-168.

Pl a th, Ulrike 2014. Vaikus „majas”. Majaisa, valitseja ja kultuurideülene ühiselu Balti ökonoomilises kirjanduses 1750-1850. - Autogenees ja ülekanne. Moodsa kultuuri kujunemine Eestis. (Collegium litterarum 25.) Toim Rein Undusk. Tallinn: Underi ja Tuglase Kirjanduskeskus, lk 26-63.

Pull at, Raimo 2016. Tallinlase asjademaailm valgustussajandil. Tallinn: Estopol. Põldvee, Aivar 2011. Viis aabitsat ja Forseliuse õppeviis. - Lugemise kunst. (Acta Bibliothecae Nationalis Estoniae 13; Libri et memoria 2.) Koost Piret Lotman. Tallinn: Eesti Rahvusraamatukogu, lk 60-122.

R a u ch, Georg von 1994. Schiller und die baltischen Provinzen. - Georg von Rauch, Schriften aus dem Nachlaß. Eessõna Michael Garleff. Tartu: Tartu Ülikooli Kirjastus, lk 54-73.

Reimo, Tiiu 2001. Raamatukultuur Tallinnas 18. sajandi teisel poolel. Tallinn: Tallinna Pedagoogilise Ülikooli Kirjastus.

Schilling, Elsbeth (Lisi) Baronin von 1982. Vom Zarenreich zur Bundesrepublik 1884-1982. Erinnerungen und Lebensweg einer Siebenundneunzigjährigen. Bonn-Bad Godesberg.

Schroeder, Hans von 1943. Pratchen. Edeldreiste Geschichten aus baltischen Landen. Posen: Bruhns.

Schwartz, August Wilhelm Theodor 2007. Erinnerungen eines älteren Semesters. Aus meinem Leben. Kd 1. Koost Paul-G. Schwartz. Lempäälä.

St a ckelberg, Eduard 2010. Ühe baltlase võitlustee. Püüdlused, võidud ja kaotused. Tlk Reet Bender. (Eesti mälu 38.) Tallinn: Eesti Päevaleht, Akadeemia.

St a d e n, Berndt von 2004. Mälestusi kadunud maailmast. Noorusaastad Baltikumis 1919-1939. Tlk Hanna Miller. (Liivimaa klassika.) Tallinn: Huma.

Stein w a d, Marie 1968. Meine Schulerinnerungen aus Dorpat. Koost Georg von Rauch. Hamburg: Harry von Hofmann.

Sternfeldt, Marie 2010. Ehitusmeistri naine. Tartu ehitusmeistri Wilhelm Sternfeldti abikaasa mälestused 1872-1917. Tartu: Eesti Rahva Muuseum.

Taube, Otto von 1944. Im alten Estland. Kindheitserinnerungen. Stuttgart: K. F. Köhler Verlag.

Reet Bender (snd 1974), PhD, Tartu Ülikool, maailma keelte ja kultuuride kolledž, saksa filoloogia lektor, reet.bender@ut.ee 


\section{On books and reading as reflected in Baltic German memoir literature}

Keywords: memoirs, Baltic German cultural history, history of reading, reading acquisition

The article discusses the references to reading and learning to read in Baltic German memoirs. It also introduces some new sources, which are particularly valuable for containing information on everyday history. The examples represent the period from the late $18^{\text {th }}$ century to the interval between the two World Wars. Despite the long period of report, as well as the social diversity and gender heterogeneity of the list of authors (e.g. Baer, Anders, Schwartz, Ostwald, Hunnius, Kentmann, Hartge, Bodisco, Taube, Staden etc.) it is notable that reading and books have often been considered worthy of discussing in memoirs. In most cases it is described how one learned to read (here the mother's role can hardly be overestimated), adolescent reading experiences (as an important part of personality development) and the procurement of reading material. Adult reading habits can rather be deduced from indirect evidence, such as, e.g. mentions of reading to children or family, which was a popular pastime in Baltic German Biedermeier homes. The second half of the $19^{\text {th }}$ century brings conscious guidance of children in the choice of reading materials, and also an accumulation of books in homes, due to improved conditions for publishing and bookselling as well as to economic growth in the Baltic provinces. University students, in addition, had access to the voluminous libraries of student corporations. The authors and texts referred to in the memoirs testify to a continuous consumption of culture, keeping in step with Germany and in touch with all fashionable and topical texts. A vital issue was the example of other family members and the availability of books to rouse and develop mental and spiritual interests in children, which was, however, done in a natural combination with other activities, without becoming an end in itself.

Reet Bender (b. 1974), PhD, University of Tartu, College of World Languages and Cultures, lecturer of German Philology, reet.bender@ut.ee 